\title{
THE CHRONIC FAILURE
}

By JoHN BORRIE, M.B.E., F.R.C.S.

'There are 400 in the doldrums, becalmed between Primary and Final.'

I never read through the list of successful candidates of a Fellowship examination without wondering ' how many also failed, and why ?'

There is an art in passing an examination; there is an art in failing. How many really understood why they did fail ? How many had truthfully and conscientiously studied their subject from all theoretical and practical angles? How many worked consistently, really attempted to think about what they read, or attempted to write down their muddled ideas before the great day dawned? How many practised writing test questions.? and how many thought that their effort was a "genuine worth-while attempt' and not just ' another shot'? Life gives little to those that make 'odd shots '; and remember no one can have another shot at life.

If you are a chronic failure, and I mean that in no belittling sense, have you ever asked yourself 'On what does an examiner pass a candidate?' For as sure as night follows day a worth-while examiner has his high standards, and he will expect yours to be high, too.

First, he wants to know if you can write lucid English in a neat legible hand. English is a lovely language, and writing a reasonable art. Perhaps neat writing means careful operating.

Secondly, he wants you to write a short, concise, finished article as for a medical journal. Disconnected thoughts, rudely précised, are anathema to any self-respecting examiner. So, too, is a never-ending scrawl. Who knows but he may have to read your paper at 3 a.m. in the morning, and unless it is well arranged what examiner can resist being severe? He is human, too.

Thirdly, he wants you to reveal a wide appreciation of the subject, and an ability to summarize and apply knowledge, not merely to quote chapter and verse parrot fashion.

Fourthly, and very important, in the clinical examination, after an accurate examination and short deliberation, you are expected to give a clear, concise, surgical opinion and to show a detailed knowledge of how to treat the patient well.

Fifthly, your attitude to surgery must be healthy. You are expected to be a man, a man of wide understanding and, above all, a good doctor. I am sure that sense impression counts more than most realize. Think, therefore, on these things.

Much of what is required can only be found by working in various centres, knocking around oro being knocked around, studying long and wellos discussing, travelling and never letting any piece of useful knowledge escape notice. Like Rem-n brandt, learn to paint a wide canvas, and like Rembrandt, you may expect results.

When you are in that all-important viva voce examination, your attitude must not be that of a business man out to catch a man who is out tog catch you. Even if you feel that 8-I I Queen's Square is one of the best investments in Londoni today, paying the highest dividends (but not tor you), do not show it in the examination. Neithere go there in a state of high tension with the idea'I must get through, my life depends on it.' You cannot set the pace of those last few hours that ${ }^{-}$ crown your months of work. Since they are in- $\vec{c}$ evitable, relax and enjoy them.

Rather go there determined, as a would-be junior consultant, to do all you can to help the pundits with some difficult consultations. Thgt, $\vec{c}$ after all, is why you are called there. Remembe too, to treat the patient as a patient and not as the extraordinary Victorian inanimate object, a casec.o (P.S. I look to the day when the word ' case' is relegated to the linguistic rubbish heap.)

I am impressed by the number of candidates who, often engaged in specialist work, honestly and wrongly believe that a few odd hours a month, $\overrightarrow{\overrightarrow{0}}$ with an occasional snap-visit to a general surgical $\exists$ clinic, can fit them for their ordeal. The con-? ditions of the examination are clearly set down. Constantly appearing in Queen's Square in the hope that a mass sympathetic vote from the left: will grant the coveted laurels, has never yet been 3 proved true. It is interesting to note that even: the examiners are now wise to this ruse and, with genuine goodwill and a desire to save wilful waste of golden guineas, have started referring can-? didates for a year. One may add ' you have been weighed in our particular balance and found? wanting.' Go ye therefore into the highways and N byways, learn life, learn surgery and return with maturer ideas and maturer ideals; and, for your encouragement, remember the wise words of $\omega$ John Kirk:-

'Failure is but victory delayed.'

'If we should fail ?'

'We fail! But screw your courage to the sticking place and we'll not fail !'

Courage friend. ' Ne illegitimus carborundum.' 